Journal of Bangladesh Academy of Sciences, Vol. 37, No. 2, 195-203, 2013

\title{
PREPARATION AND CHARACTERIZATION OF IRON(III) COMPLEX OF SACCHARIN
}

TAJ AL TANVIR, MD. ELIUS HOSSAIN, MOHAMMAD AL MAMUN AND

M. Q. EHSAN ${ }^{*}$

Department of Chemistry, University of Dhaka, Dhaka-1000, Bangladesh

\begin{abstract}
Complex of iron(III) with saccharin, $\left[\mathrm{Fe}\left(\mathrm{C}_{7} \mathrm{H}_{4} \mathrm{O}_{3} \mathrm{SN}\right)_{2} \mathrm{Cl}\right]$ has been prepared in aqueous medium. The IR and electronic spectral analysis suggest that two saccharin molecules are attached to the metal ion through $\mathrm{N}$ atom and there is no chemically coordinated or crystalline water in the complex molecule. The magnetic moment value indicates the paramagnetic character of the complex. The cyclic voltammetric study indicates a quasi-reversible electron transfer process due to the presence of iron in the compound.
\end{abstract}

Key words: Characterization, Iron(III) complex, Saccharin

\section{INTRODUCTION}

Metal and metal ions are important for all living system. Among them iron is essential to all organisms. Iron is vital for almost all living organisms which participate in a wide variety of metabolic processes, including oxygen transport, DNA synthesis, and electron transport (Lieu et al. 2001). As a functional component of heme, iron participates in oxygen transport by hemoglobin (Ponka 1999) and drug detoxification by cytochrome P450 in liver (Danielson 2002). Iron present as Fe(III) in protoporphyrin is used as oxygen carrier and maintains the circulation of oxygen in the body by redox reaction.

Saccharin is a ligand, which can act as a mono dentate, bi dentate and tetra dentate ligand. So it may form coordination bond with the transition metal ion. However, saccharin is used as pharmaceutical excipients in the formulation of different medicinal products like syrup, suspension as a sweetening agent (Kibbe 2000). In biological system, especially in human body the actual mechanism of electrochemical interaction between the essential trace element like Fe and saccharin of the drug excipients need to be investigated. Very few investigations have been reported about these pharmacological phenomena (Negro 1994). Moreover, iron is the main constituent of blood. Therefore a basic knowledge about its redox behaviour in the presence of different ligands and at different $\mathrm{pH}$ values is very important. Various electrochemical techniques are useful for studying the redox behavior of electro active species. Cyclic voltammetry has been

\footnotetext{
${ }^{*}$ Corresponding author:
} 
chosen for this present study because of its effectiveness in investigation of the redox behaviour of electro active species. Many papers about metal-saccharin complexes have been published from our laboratory (Romman et al. 1993, Malik et al. 1999, Romman et al. 1999, Ahmed et al. 1981, Haider et al. 1992). In the present paper we report the preparation of iron saccharin complex and its speciation by different chemical, physicochemical and spectroscopic analysis. In addition, the redox behavior of the complex was studied on GCE, Au and Pt electrode using cyclic voltammetric technique.

\section{MATERIALS AND METHODS}

All the chemicals, solvents and ligand used in the synthesis and analytical work were Analar grade obtained from E. Merck of Germany. Iron content of the complex was determined by titrimetric method. The iron(III) in the complex was reduced to iron(II) then titrated with $\mathrm{K}_{2} \mathrm{Cr}_{2} \mathrm{O}_{7}$ (Bassett et al. 1989). The percentage of $\mathrm{C}, \mathrm{H}, \mathrm{S}, \mathrm{N}$ and $\mathrm{Cl}$ were determined by an elemental analyzer at Tohoku University, Japan. Infrared spectra of saccharin and the complex were recorded on a calibrated Fourier Transform IR Spectrophotometer (FTIR, 8300, Shimadzu, Japan) in the range of $400-4600 / \mathrm{cm}^{-1}$ using $\mathrm{KBr}$ pallets. The UV-visible spectrum of the complex was recorded using UV-visible Spectrophotometer, Model UV-160A, Shimadzu (Japan), in the wavelength range, 200$1100 \mathrm{~nm}$ using paraffin oil as dispersion medium. Magnetic moment of the complex was determined using Sherwood Scientific Magnetic Susceptibility Balance, Cambridge, England, and Model: Magway MSB Mk1. The MSB works on the basis of a stationary sample and moving magnets.

Cyclic voltammetric (CV) studies were conducted with a PC controlled potentiostate, Epsilon Electrochemical Analyzer; developed by Bioanalytical System, Inc. U.S.A. A three-electrode electrochemical cell made of borosilicate glass and Teflon cap was used in this study: Glassy carbon (GC), Au and Pt were used as working electrode, $\mathrm{Ag} / \mathrm{AgCl}$ (standard $\mathrm{KCl}$ ) was used as reference electrode and $\mathrm{Pt}$ wire as counter electrode. 99.997\% nitrogen (Bangladesh Oxygen Ltd.) was used for purging purpose and deionized water was used for cyclic voltammetric study. The working electrode was cleaned by polishing on cloth using alumina powder. Solutions of ironsaccharin complex were prepared in deionized water.

Method of preparation: The aqueous solutions of the ligand $(1.025 \mathrm{~g}$ in $20 \mathrm{~mL}$ water $)$ and $\mathrm{FeCl}_{3}(0.815 \mathrm{~g}$ in $20 \mathrm{~mL}$ water $)$ were prepared separately and then mixed at room temperature. The reaction mixture was heated to about 50 to $60^{\circ} \mathrm{C}$ on a waterbath for about half an hour and kept at room temperature for crystallization. Red crystals were separated by filtration, washed with deionized water and dried over silica gel in a 
desiccator. The microanalytical data of $\mathrm{C}, \mathrm{H}, \mathrm{N}, \mathrm{S}, \mathrm{Cl}$ and the metal content in the prepared complex are,



Anal found for $\left[\mathrm{Fe}\left(\mathrm{C}_{7} \mathrm{H}_{4} \mathrm{O}_{3} \mathrm{SN}\right)_{2} \mathrm{Cl}\right],(\%): \mathrm{C}, 37.15 ; \mathrm{H}, 2.16 ; \mathrm{N}, 6.33 ; \mathrm{S}, 12.47 ; \mathrm{Cl}, 6.96 ; \mathrm{Fe}, 12.98$.

Calcd for $\left[\mathrm{Fe}\left(\mathrm{C}_{7} \mathrm{H}_{4} \mathrm{O}_{3} \mathrm{SN}\right)_{2} \mathrm{Cl}\right],(\%): \quad \mathrm{C}, 36.81 ; \mathrm{H}, 1.77 ; \mathrm{N}, 6.14 ; \mathrm{S}, 14.05 ; \mathrm{Cl}, 7.79 ; \mathrm{Fe}, 12.26$.

\section{RESULTS AND DISCUSSION}

The good agreement between analytical and calculated data for the elements suggests that the prepared complex is pure. It is insoluble in most of the common organic solvents such as methanol, ethanol, DMSO etc. but soluble in water and dilute mineral acids. The complex decomposes at 200 to $235^{\circ} \mathrm{C}$.

IR spectral analysis: The IR spectra of saccharin $\left(\mathrm{C}_{7} \mathrm{H}_{5} \mathrm{O}_{3} \mathrm{SN}\right)$ and $\left[\mathrm{Fe}\left(\mathrm{C}_{7} \mathrm{H}_{4} \mathrm{O}_{3} \mathrm{SN}\right)_{2} \mathrm{Cl}\right]$ were studied in detail. The tentative assignments have been done on the basis of some standard references (Pavia et al. 2001, Silverstein et al. 1981, Nakamoto 1978, Rao 1963). The important characteristic vibrational frequencies and their tentative band assignments are:

$$
\begin{aligned}
& \mathrm{C}_{7} \mathrm{H}_{5} \mathrm{O}_{3} \mathrm{SN}\left(v, \mathrm{~cm}^{-1}\right) \quad: 3535 v_{\mathrm{str}}(\mathrm{N}-\mathrm{H}), 2362 v_{\mathrm{str}}(\mathrm{C}-\mathrm{S}), 1647 v_{\mathrm{st}}(\mathrm{C}=\mathrm{O}), \\
& 1450 v(\mathrm{C}=\mathrm{C} \mathrm{Ar}), 1259 v_{\mathrm{str}}(\mathrm{C}-\mathrm{N}), 1151 v_{\mathrm{str}}(\mathrm{C}-\mathrm{O}) . \\
& {\left[\mathrm{Fe}\left(\mathrm{C}_{7} \mathrm{H}_{4} \mathrm{O}_{3} \mathrm{SN}\right)_{2} \mathrm{Cl}\right]\left(v, \mathrm{~cm}^{-1}\right): 2320 v_{\mathrm{str}}(\mathrm{C}-\mathrm{S}), 1718 v_{\mathrm{str}}(\mathrm{C}=\mathrm{O}), } \\
& 1593 v(\mathrm{C}=\mathrm{C} \mathrm{Ar}), 1336 v_{\mathrm{str}}(\mathrm{C}-\mathrm{N}), 1176 v_{\mathrm{str}}(\mathrm{C}-\mathrm{O}) .
\end{aligned}
$$

In saccharin the bands for stretching vibration of N-H and C-S are found at 3535 and $2362 \mathrm{~cm}^{-1}$ respectively. The absorption band for stretching vibration of $(\mathrm{C}=\mathrm{O})$ appeared at $1647 \mathrm{~cm}^{-1}$. The absorption bands in the region 1333 to $1553 \mathrm{~cm}^{-1}$ is for $\mathrm{C}=\mathrm{C}$ in the aromatic ring, $1259 \mathrm{~cm}^{-1}$ for $\mathrm{C}-\mathrm{N}$ single bond, and at $1151 \mathrm{~cm}^{-1}$ for $\mathrm{C}-\mathrm{O}$ single bond.

The FTIR spectrum of the complex strongly support that there is no crystalline or chemically coordinated water, since there is no significant absorption band for $\mathrm{OH}$ stretching of $\mathrm{H}_{2} \mathrm{O}$ molecule around $3500 \mathrm{~cm}^{-1}$.

The band for stretching vibration $v(\mathrm{NH})$ completely disappeared due to the coordination of imide group through nitrogen atom with metal ion in the complex and the replacement of hydrogen. A symmetric stretching vibration of $(\mathrm{C}=\mathrm{O})$ appeared in the region $1718 \mathrm{~cm}^{-1}$ instead of $1647 \mathrm{~cm}^{-1}$ in ligand. The absorption band appears in the region 1458 to $1593 \mathrm{~cm}^{-1}$ for $\mathrm{C}=\mathrm{C}$ in the aromatic ring, $1336 \mathrm{~cm}^{-1}$ for $\mathrm{C}-\mathrm{N}$ single bond, $1176 \mathrm{~cm}^{-1}$ for $\mathrm{C}-\mathrm{O}$ single bond which are shifted in the complex due to complexation of saccharin with iron. 
Electronic spectral analysis: The electronic spectrum of the Fe-saccharin complex is shown in Fig. 1. The assignments have been done on the basis of some standard references (Lang 1961, Gillam and Strem 1957, Jatte and Orchin 1962). The absorption bands between $200-350 \mathrm{~nm}$ are observed for the ligand part of the complex and that at higher wave length is due to the metal ion. The $n \rightarrow \sigma^{*}$ absorption bands appeared at $295 \mathrm{~nm}$ and the $\mathrm{n} \rightarrow \pi^{*}$ transition band appeared at $\sim 307-350 \mathrm{~nm}$. The broad bands centering around 412 may be assigned for the d-d electronic transition and CT transition of the metal. The $\mathrm{d} \rightarrow \mathrm{d}$ transition supports the colored appearance of the complex.

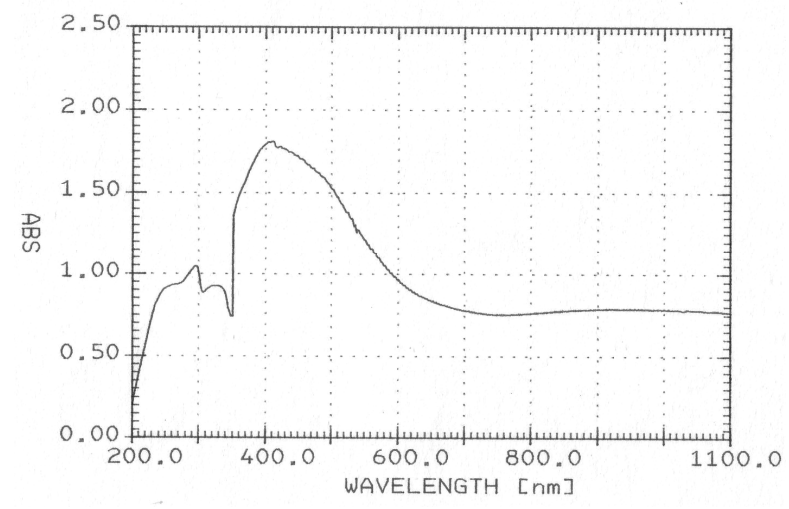

Fig. 1. UV-visible spectrum of $\left[\mathrm{Fe}\left(\mathrm{C}_{7} \mathrm{H}_{4} \mathrm{O}_{3} \mathrm{SN}\right)_{2} \mathrm{Cl}\right]$.

Magnetic properties: This study revealed that the Fe-Sac complex has $\mu_{\text {eff }}, 2.0414$ $\mathrm{BM}$ corresponding to the presence of one unpaired electron in the $3 \mathrm{~d}$ orbital (Mamun et al. 2011). This means in this complex iron is in the trivalent oxidation state, $\mathrm{Fe}^{3+}$ with $\mathrm{d}^{5}$ electronic configuration. Since magnetic properties is directly related to the d-electron arrangements of the transition metal ions, the $\mathrm{Fe}^{3+}$ ion is paramagnetic having the electronic arrangement in $3 \mathrm{~d}$ level as $\mathrm{t}_{2 \mathrm{~g}}{ }^{5} \mathrm{e}_{\mathrm{g}}{ }^{0}$. However, the $\mu_{\text {eff }}$ value reveals the low spin paramagnetic nature of the complex.

Quasi-static thermogravimetric (QSTG) analysis: The QSTG curve (Fig. 2) shows that the first step weight-loss is about $0.07 \%$. This is due to the loss of adhering surface water of the sample. The second weight loss during the decomposition of the compound is $(\sim 11 \%)$ below $235^{\circ} \mathrm{C}$, this weight loss correspond to loss of two molecules of $\mathrm{CO}$ due to the decomposition of two carbonyl groups present in the complex molecule. The next weight loss up to $700^{\circ} \mathrm{C}$ may be due to loss of 2 molecules of $\mathrm{NH}_{3}$ and $\mathrm{SO}_{2}$. The lost step weight loss before attaining the constant weight at higher temperature may be due to the removal of most of the organic part of the complex as $\mathrm{H}_{2}, \mathrm{CH}_{4}$ etc. The remaining constant weight, $15 \%$ which corresponds to the weight of $\mathrm{FeO}$. 


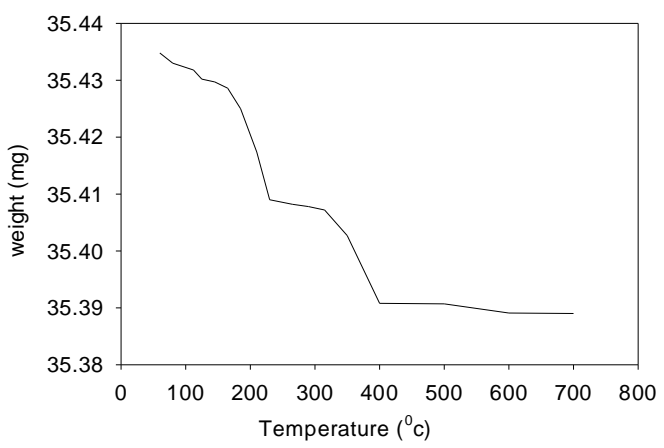

Fig. 2. QSTG curve of $\left[\mathrm{Fe}\left(\mathrm{C}_{7} \mathrm{H}_{4} \mathrm{O}_{3} \mathrm{SN}\right)_{2} \mathrm{Cl}\right]$.

The QSTG analysis may be summarized as follow:

\begin{tabular}{|c|c|c|c|c|}
\hline \multirow[b]{2}{*}{ Sample ID } & \multirow{2}{*}{$\begin{array}{l}\text { Weight of } \\
\text { the sample } \\
(\mathrm{mg})\end{array}$} & \multicolumn{2}{|c|}{ Decomposition pattern } & \multirow[b]{2}{*}{ Probable finding } \\
\hline & & $\begin{array}{l}\text { Decomposition } \\
\text { temperature }{ }^{\circ} \mathrm{C}\end{array}$ & $\begin{array}{l}\% \text { weight } \\
\text { loss }\end{array}$ & \\
\hline \multirow[t]{3}{*}[\mathrm{Fe}(\mathrm{C}_{7}\mathrm{H}_{4}\mathrm{O}_{3}\mathrm{SN})_{2}\mathrm{Cl}]{} & 35.4348 & $50-235$ & 0.07 & $\begin{array}{l}\text { May be due to loss of } \\
\text { moisture }\end{array}$ \\
\hline & & & 11.45 & $\begin{array}{l}\text { two molecules CO may be } \\
\text { lost }\end{array}$ \\
\hline & & $335-700$ & 75.98 & $\begin{array}{l}\text { One molecule each of } \mathrm{SO}_{2} \\
\text { and } \mathrm{NH}_{3} \text { may be lost, } \\
\text { followed by total } \\
\text { decomposition of organic } \\
\text { part as } \mathrm{H}_{2}, \mathrm{CH}_{4} \text { etc. } \\
\text { Residue about } 15.12 \% \\
(\mathrm{FeO})\end{array}$ \\
\hline
\end{tabular}

Cyclic voltammetric studies: The redox behavior of $\mathrm{Fe}(\mathrm{III})$ in $\left[\mathrm{Fe}\left(\mathrm{C}_{7} \mathrm{H}_{4} \mathrm{O}_{3} \mathrm{SN}\right)_{2} \mathrm{Cl}\right]$ in aqueous medium was observed using $\mathrm{CV}$ technique on $G C, \mathrm{Au}$ and $\mathrm{Pt}$ electrode at the scan rate $100 \mathrm{mV} \mathrm{s}^{-1}$ within the potential window 1.2 to $-1.0 \mathrm{~V}$ at room temperature. The $\mathrm{CV}$ of $\mathrm{Fe}$ (III) in the complex and that of the free ligand, at Au electrode are shown in Fig. 3.

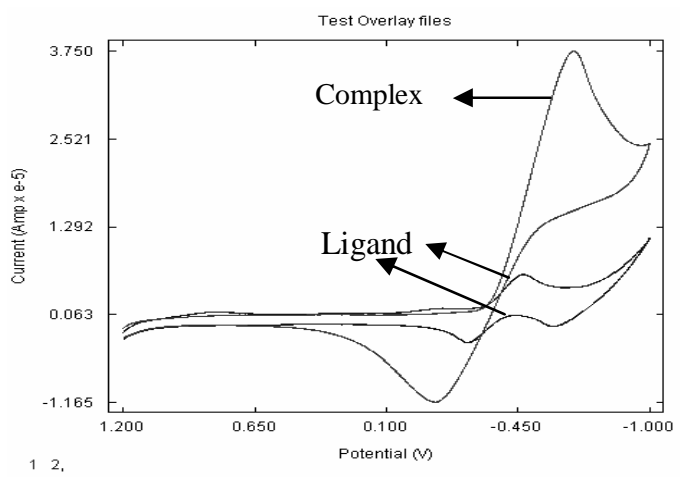

Fig. 3. Cyclic voltammograms of $\mathrm{Fe}(\mathrm{III})$ complex and free saccharin at $\mathrm{Au}$ electrode vs. $\mathrm{Ag} / \mathrm{AgCl}$. 
The CV of Fe(III)-complex shows a cathodic peak at the potential - $0.6757 \mathrm{~V}$ and an anodic peak at $-0.07801 \mathrm{~V}$ on Au electrode. The cyclic voltammogram indicate that there is a one -electron transfer process i.e.

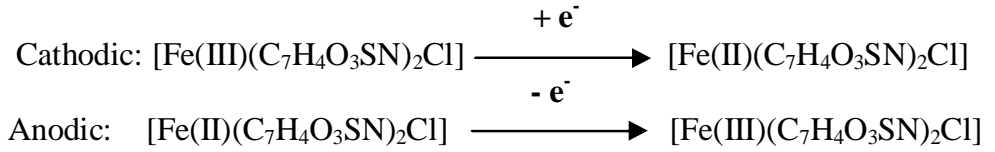

Variation of scan rate: The cyclic voltammograms of $\mathrm{Fe}(\mathrm{III})$ complex in aqueous medium at $\mathrm{Au}$ electrode $v s \mathrm{Ag} / \mathrm{AgCl}$ at different scan rate are displayed in Fig. 4(a) and the current-potential data, peak separation, peak current ratio of the voltammograms are recorded in Table 1. The plot of peak current vs SQRT of scan rate is shown in Fig. 4 (b).

The voltammograms of the complex at different scan rate express that with the increase of scan rate the peak current of both the anodic and cathodic peaks increase. However, the cathodic peaks are shifted towards right and the anodic peaks are shifted to the left direction. In a slow voltage scan the diffusion layer grows much further from the electrode in comparison to a fast scan. Consequently, the flux to the electrode surface is considerably smaller at slow scan rates than it is at faster rates. As the current is proportional to the flux towards the electrode, the magnitude of the current becomes lower at slow scan rates and higher at high scan rates. The general conclusion is that the redox system is diffusion controlled (David and Gosser 1993).

Table 1. Current-potential data, peak separation, peak current ratio of the voltammograms of Fe-Sac at different scan rates on Au electrode.

\begin{tabular}{ccccccc}
\hline $\begin{array}{c}\text { Scan rate } \\
(v) \mathrm{Vs}^{-1}\end{array}$ & $\begin{array}{c}\text { Anodic peak } \\
\text { potential, } \mathrm{E}_{\mathrm{pa}} \\
\mathrm{V}(-)\end{array}$ & $\begin{array}{c}\text { Cath }^{\mathrm{c}} \text { peak } \\
\text { potential, } \\
\mathrm{E}_{\mathrm{pc}} \mathrm{V}(-)\end{array}$ & $\begin{array}{c}\text { Anodic peak } \\
\text { current, } \mathrm{i}_{\mathrm{pa}} \mu \mathrm{A} \\
(-)\end{array}$ & $\begin{array}{c}\text { Cath }^{\mathrm{c}} \text { peak } \\
\text { current, } \mathrm{i}_{\mathrm{pc}} \mu \mathrm{A}\end{array}$ & $\begin{array}{c}\text { Peak separation, } \\
\Delta \mathrm{E}=\left(\mathrm{E}_{\mathrm{pa}}-\mathrm{E}_{\mathrm{pc}}\right) \mathrm{V}\end{array}$ & $\begin{array}{c}\text { Peak current } \\
\text { ratio, } \mathrm{i}_{\mathrm{pa}} / \mathrm{i}_{\mathrm{pc}}\end{array}$ \\
\hline 0.050 & 0.2327 & 0.5627 & 1.7024 & 2.8005 & 0.3315 & 0.6078 \\
0.100 & 0.2275 & 0.5967 & 1.4376 & 3.7265 & 0.3692 & 0.3857 \\
0.150 & 0.2158 & 0.6332 & 1.1872 & 4.2092 & 0.6950 & 0.2820 \\
0.200 & 0.2086 & 0.6512 & 0.9067 & 4.5471 & 0.7038 & 0.1994 \\
\hline
\end{tabular}
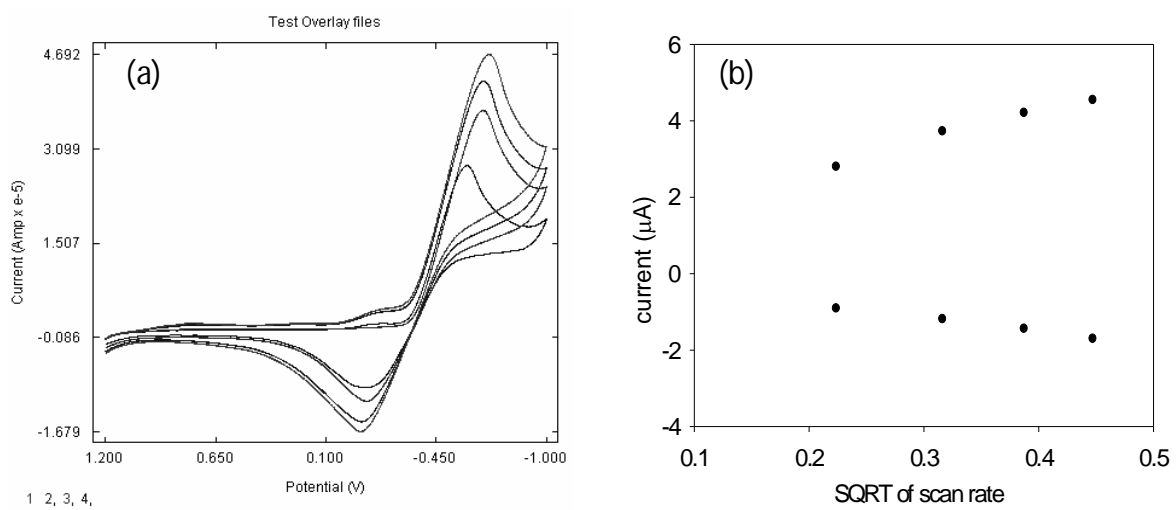

Fig. 4. Cyclic voltammograms of $\mathrm{Fe}-\mathrm{Sac}$ complex in aqueous medium on $\mathrm{Au}$ electrode $v s \mathrm{Ag} / \mathrm{AgCl}$ at (a) different scan rate and (b) the variation of peak current with sq. root of scan rate. 
Fig. $4 \mathrm{~b}$ indicates that the linear plot for anodic process passes through origin whereas that for cathodic process does not, which may be due to the fact that the electrode process on the cathode is to some extent adsorptive controlled (Bard and Faulkner 1980).

The variation of peak potential separation with scan rate for the complex at $\mathrm{Au}$ electrode $v s \mathrm{Ag} / \mathrm{AgCl}$ at different scan rate are displayed in Fig. 5. It is found that with the increase of scan rate the peak separation increases. The ratio of the anodic and cathodic peak current for the electroactive species is quite smaller than unity and decreases with scan rate. These observations suggest that the system is not reversible but it may be called as quasi reversible process (Mamun et al. 2011).

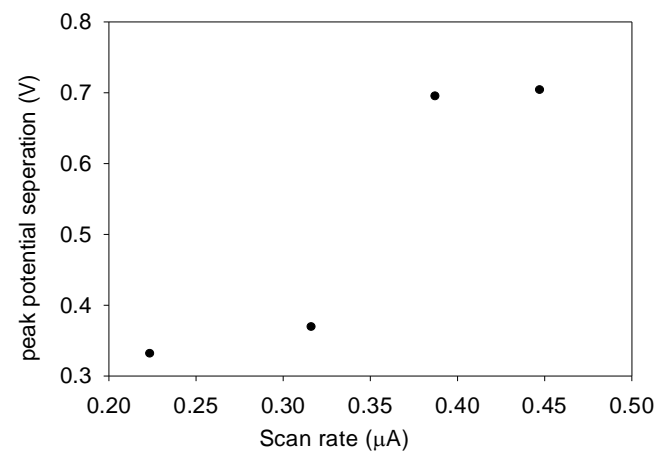

Fig. 5. Variation of peak potential separation with scan rate for Fe-Sac complex on Au electrode $v s \mathrm{Ag} / \mathrm{AgCl}$ at different scan rate.

Effect of electrode material: The redox behavior of $\mathrm{Fe}(\mathrm{III})$ in the complex at different electrodes are shown in Fig. 6. Pair of cathodic and anodic peaks is found on $\mathrm{Au}$ electrode. However, two pairs of cathodic and anodic peaks appeared on Pt electrode. On $G C$ electrode no significant response was found.

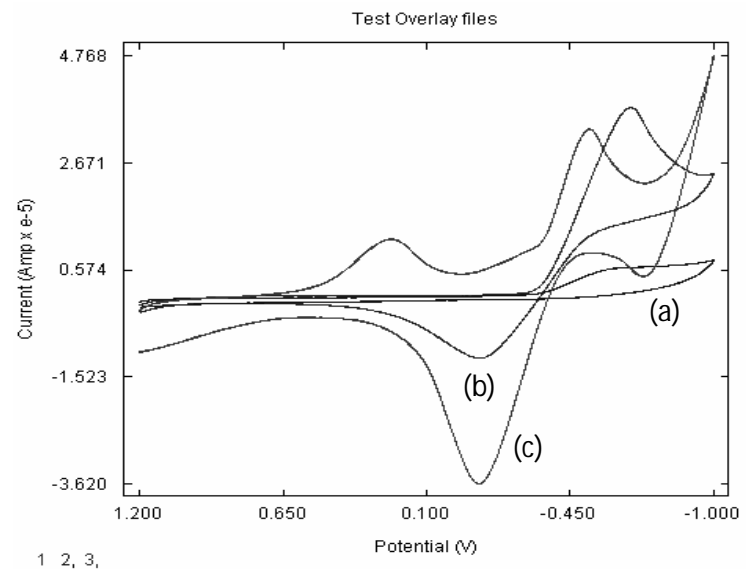

Fig. 6. Cyclic voltammetric response of the Fe(III) in the complex at (a) GCE, (b) $\mathrm{Au}$ and (c) Pt electrode vs. $\mathrm{Ag} / \mathrm{AgCl}$. 
With the variation of electrode material the redox behavior of $\mathrm{Fe}(\mathrm{III})$ in the complex changes significantly regarding the number, position and current of both the cathodic and anodic peaks. It is difficult to explain this behaviour exactly, but one thing may be said that the mechanism of the electrode processes on different surfaces is quite different (Bard and Faulkner 1980). At gold electrode the voltammogram shows usual pattern for $\mathrm{Fe}(\mathrm{II})-\mathrm{Fe}$ (III) system. The voltammogram of Fe(II)-Fe(III) system of the complex at Pt electrode is very much unusual, it contains two pair of cathodic and anodic peaks which needs further investigation for proper explanation.

\section{ACKNOWLEDGEMENT}

Thanks are due to Dr. S. Yamauchi, Professor of Tohoku University, Japan for supplying the elemental analysis data.

\section{REFERENCES}

Ahmed, K. J., K. M. A. Malik, and S. Z. Haider. 1981. Synthesis and Some Properties of MetalSaccharin Complexes with General Formula $\left[\mathrm{M}\left(\mathrm{C}_{7} \mathrm{H}_{4} \mathrm{NO}_{3} \mathrm{~S}\right)_{2}\left(\mathrm{H}_{2} \mathrm{O}\right)_{4} \cdot\left(\mathrm{H}_{2} \mathrm{O}\right)\right.$, J. Bangladesh Acad. Sci. 5(2): 81.

Bard, A. J. and L. R. Faulkner. 1980. Electrochemical Methods, Fundamentals Applications. NY, USA: John Wiley and Sons, pp. 199.

Bassett, J., R. C. Denney, G. H. Jeffery and J. Mendham. 1989. Vogel's Text Book of Quantitative Inorganic Analysis. London, UK: ELBS, 329.

Danielson, P.B. 2002. The cytochrome P450 superfamily: Biochemistry, evolution and drug metabolism in humans. Curr. Drug Metab. 3: 561-597.

David, K. and J. Gosser. 1993. Cyclic Voltammetry, Simulation and Analysis of Reaction Mechanisms. NY, USA: Wiley-VCH, pp. 43.

Gillam, A. E. and E. S. Strem. 1957. An Introduction to Electronic Absorption Spectroscopy in Organic Chemistry. London, UK: Arnold, pp. 175.

Haider, S. Z., K. M. A. Malik, U. K. R. Romman and M. B. Hursthouse. 1992. Synthesis, Characterization and Properties of Some Metal- Saccharin Complexes Containing Pyridine and 2,6diacetyl pyridine as Secondery Ligand, J. Bangladesh Acad. Sci. 16(2): 159-168.

Jatte, H. H. and M. Orchin. 1962. Theory and Applications of Ultraviolet Spectroscopy. NY, USA: John Wiley and Sons, pp. 132.

Kibbe, A. H. 2000. Handbook of Pharmaceutical Excipients. London, UK.

Lang, L. 1961. Absorption spectra in the Ultraviolet and Visible Region. NY, USA: Academic Press, pp. 57.

Lieu, P. T., Heiskala, M., Peterson, P. A. and Y. Yang. 2001. The roles of iron in health and disease. Molecular Aspects of Medicine 22: 87.

Malik, K. M. A., U. K. R. Romman and S. Z. Haider. 1999. Synthesis, Characterization and Properties of Some Complexes of Saccharin with Some Alkali Metals. J. Bangladesh Chem. Soc. 12(1): 35 . 
Mamun, M. A., O. Ahmed, P. K. Bakshi, S. Yamauchi and M. Q. Ehsan. 2011. Synthesis and characterization of some metal complexes of cysteine. Russian Journal of Inorganic Chemistry 56(12): 1972-1980.

Nakamoto, K. 1978. IR and Raman Spectra of Inorganic and Coordination Compounds. NY, USA: John Wiley and Sons. 305.

Negro, F. 1994. Hepatotoxicity of saccharin. N. Engl. J. Med. 331: 134-5.

Pavia, D. L., G. M. Lampman and G. S. Kriz. 2001. Introduction to Spectroscopy. Belmont, USA, pp. 13.

Ponka, P. 1999. Cell biology of heme. Am. J. Med. Sci. 318: 241-256.

Rao, C. N. R. 1963. Chemical Applications of IR Spectroscopy. NY, USA: Academic Press, pp. 364 .

Romman, U. K. R., K. M. A. Malik and S. Z. Haider. 1999. Synthesis, Characterization and Properties of some Saccharine Complex Containing 1,10-phenanthroline as Secondary Ligand. $J$. Bangladesh Chem. Soc. 6(1): 43-50.

Romman, U. K. R., K. M. A. Malik and S. Z. Haider. 1999. Synthesis, Characterization and Properties of some Saccharine Complex Containing 2,2'-bipyridine as Secondary Ligand. $J$. Bangladesh Acad. Sci. 23(2): 155.

Silverstein, R. M., F. X. Webster and D. J. Kiemle. 1981. Spectroscopic Identification of Organic Compounds. NY, USA: John Wiley, pp. 135.

(Received revised manuscript on 20 October, 2012) 